\title{
QUALITY ASSESSMENT OF URBAN TREES USING GROWTH VISUAL AND CHLOROPHYLL FLUORESCENCE INDICATORS
}

\author{
PETER UHRIN, JÁN SUPUKA
}

Slovak University of Agriculture in Nitra, Faculty of Horticulture and Landscape Engineering, Department of Garden and Landscape Architecture, Tr. A. Hlinku 2, 94976 Nitra, Slovak Republic; e-mail: petuhrin@hotmail.com, jan.supuka@uniag.sk

\begin{abstract}
Uhrin P., Supuka J.: Quality assessment of urban trees using growth visual and chlorophyll fluorescence indicators. Ekológia (Bratislava), Vol. 35, No. 2, p. 160-172, 2016.

Urbanised landscape represents composed structures of technical and biotic elements where social and economy activities create living space for human society but with strongly changed environment. To dominant characters belong climate changes with increased air temperature, drought and emission load, which has developed wide spectrum of stress factors influencing the urban vegetation. For the assessment of plant growth and adaptation response, we have used Sycamore maple (Acer pseudoplatanus L.) as study model woody plant. In the framework of visual characters, we assessed the following indicators: (a) assimilation organs (leaf necrosis); (b) crown quality (degree of foliage and degree of dead tree crown); (c) trunk and branch quality (mechanical damage, incidence of wood destroying fungus and trunk cavities and callus healing of trunk wounds). Each indicator was assessed in five-point scale, and in the end, the common index of quality was calculated. The quality index achieved 9.33 points in the first and 10.33 in the second evaluation periods in the Nitra city and 2.66 at the both assessed periods in the comparable rural park. In the group of physiological indicators, chlorophyll $a$ fluorescence marker and its $\mathrm{F}_{\mathrm{v}} / \mathrm{F}_{\mathrm{m}}$ parameter were used. Within three repeating assessment during growing season (June, August and September), the average values reached $\mathrm{F}_{\mathrm{v}} / \mathrm{F}_{\mathrm{m}}=0.814$ in the city and $\mathrm{F}_{\mathrm{v}} / \mathrm{F}_{\mathrm{m}}=0.829$ in rural park. The results confirmed statistical significances between loaded city conditions and relatively clean rural locality. Used markers have shown as appropriate tools for growth response measurements of street trees in a changed urban environment.
\end{abstract}

Key words: urban environment, street trees, stress indicators.

\section{Introduction}

City settlements represents mixed ecosystem consist of natural and anthropogenic components. Number of population living in the cities has reached in the beginning of $21^{\text {st }}$ century $50-75 \%$ in developed countries and takes accelerating growth (Antrop, 2004). Social, economical and technological activities have caused wide spectral environment impact on urban population, plant and animal organism and also on technical infrastructure. Climate conditions are strongly changed. The air temperature reaches annual 
average values of $1.5-3.5^{\circ} \mathrm{C}$ higher than the surrounding landscape, air humidity turn down by $5-10 \%$, fog occurrence are being more often, sun radiation has decreased because of air pollution, above the cities has been created heat island that reaches till $1 \mathrm{~km}$ in high by anthropogenic and glasshouse gases heating effect (Douglas, 2012; Mc Kinney, 2006; Dobrovolný et al., 2012; Oke, 2006). The group of emission components presents gas compounds, air particles and aerosols, containing various elements including heavy metals. To most frequent gas emissions belongs $\mathrm{NO}, \mathrm{N}_{2} \mathrm{O}, \mathrm{CO}, \mathrm{CO}_{2}, \mathrm{O}_{3}, \mathrm{SO}_{2}$, those participate on glasshouse effect and on injury of the urban vegetation in wide spectral form and levels (Gilbert, 1989; Kuczman, Feriancová, 2013; Rózová et al., 2013; Supuka et al., 1991; Tóth et al., 2015). Urban soil characteristics are another factors limiting favourable growth of woody plants in green spaces. Urban soils are rather anthropogenic origin (the so-called antrosoils) and, in many cases, artificially layered spoil with improper physical and chemical structure, very often compacted, a low biotic activity, low water and nutrient content, increased content of alochtonous components originated from wet and dry deposition of emissions (Craul, 1992; Sobocká et al., 2007). The all above-mentioned features of urban environment creates potential stress factors on urban vegetation. Long-lasted summer dry period with high air temperature and almost without rainfall is currently very often and caused obvious growth and biology changes in woody plants (Quigley, 2004; Leuzinger, et al., 2010). High temperature due to increasing of the leaf evaporation (Slováková, Mistrík, 2007) in extreme conditions may caused photosynthetic disturbance and injury of assimilation organs (Střelcová, Kmet', 2003). Long-time chronic environmental stress factors lead to loss of vitality, disturbance in growth and evolution and finally to the decreasing of life span of trees in urban vegetation (Pejchal, 1997). Stress factors have developed different reactions and damages in biological systems on micro- and macroscopic levels in anatomy, morphology, physiology and biochemical features. They are assessed as bioindication markers in relation to stresses. To morphology and visible indicator belongs, for example, year increment, small leaf creation, crown density, leaf necrotic symptoms, disturbance in blooming and fruiting process, occurrence of pests and diseases on vegetative organs and wood destroying fungus (Bernatzky, 1978; Gáper, Gáperová, 2009; Innes, 1990). In the group of ecology- physiology markers of woody plant response to environmental stress takes place a chlorophyll fluorescence of the leaves. The assessment method is established on correlation fluorescence emission spectrum in relation to composition and quality of pigments (dominantly chlorophyll $a$ ) and ultrastructure of assimilation organs. In disturbed leaves, the chlorophyll fluorescence has decreasing tendency (Lichtenthaler, 1997). The method of chlorophyll $a$ fluorescence was applied during the assessment of the beech and spruce trees in forest stands (Kmet', 1999; Kmet' et al., 2009). Other articles have presented chlorophyll $a$ fluorescence in experimental study of Cornus mas L. and Spiraea japonica L. under drought stress (Paganová et al., 2015). In young pubescent oak, photosynthetic performance and chlorophyll quality in process of water deficiency were studied (Gallé et al., 2007). In city conditions, the chlorophyll $a$ fluorescence was used in the assessment of five chosen tree species grown in the streets under multi-factorial stresses (Jasenka, 2011; Supuka et al., 2010). 


\title{
Material and methods
}

\author{
Study area and assessed woody plants
}

Study was focused on the assessment of visual growth features and course of chlorophyll $a$ fluorescence parameters at Sycamore maple (Acer pseudoplatanus L.) grown in the streets of city conditions and compared with trees that are grown in rural historical park. At both the localities, the three individuals for the assessment of the mentioned tree taxa in almost similar age of 50-70 year old and average high of 10-14 m were chosen. The study was done in the year 2015 .

The first studied locality represents Nitra city with almost 90,000 populations in south-west part of Slovakia. Studied woody plants have grown in the Tr. A. Hlinku street as composition part of accompanying green belt in 20 $\mathrm{m}$ width on both sides of transport road. This transport line belongs to high environmental load locality dominantly from car and lorry vehicles, when almost 3,000 vehicles have passed via road in both courses by the one hour. To complex stress factors affecting the trees such as car's emissions, increased air temperature and drought, condition worsening urban soil, including salt effect in winter time, should be included.

Comparative locality represents historical park of 6.6 ha area in Nová Ves nad Žitavou, about $25 \mathrm{~km}$ east of Nitra city. The village is typical rural settlement with almost 1,300 residents. There are neither industrial sources nor high car transport that should worsen environmental quality, it is consider quite clean.

\section{Climate characteristic of studied territory}

For the territory of Nitra city, meteorological data obtained from weather station located in Botanical garden of SPU (SAU) in Nitra were used. For rural park of Nová Ves nad Žitavou, data from station located $4 \mathrm{~km}$ away in Arboretum Mlynany SAS were used. In order to compare climate differences between assessed localities, the follow weather dates were evaluated: air temperature, sum of precipitation. The obtained data were used for the calculation of standardised precipitation index (SPI) and standardised precipitation and evaporation index (SPEI) for the Nitra locality (Štastný et al., 2015).

\section{Assessment of tree visual characters}

For the assessment of leaf and crown quality, the following visual characters were used (according to methods of Innes, 1990; Pejchal, 1995; Supuka et al., 1991): (a) indicators of assimilation organs (leaf necrosis) and (b) indicators of crown quality (degree of foliage and degree of the tree crown mortification). For the assessment of trunk and/ or branch quality, three indicators (according to Gáper, Gáperová, 2009), such as mechanical damage, incidence of wood destroying fungus and or trunk cavities and callus healing of wounds caused by mechanical or fungus damage, were used. Above-mentioned indicators were assessed in five-point scale from 0 till 4 points (Table 3). Assessment of tree visual indicators was made at both studied localities in two periods during growing season, in the middle of August and late of September. A complex visual character of studied woody plants was evaluated according to the following equation (Supuka et al., 1991):

$$
Q n=\frac{\sum A i \cdot \mathrm{xi}+\sum B i \cdot \mathrm{xi}+\Sigma C i \cdot \mathrm{xi}}{\sum \mathrm{xi}}
$$

where On is the quality index of $\mathrm{n}$-th plant, $\mathrm{Ai}$ is the Ni-type and character of evaluated feature of $\mathrm{i}$-th quality, $\mathrm{xi}$ is the number of woody plants evaluated at studied locality.

Beside mentioned characters at all studied woody plants, dendrometric values, such as tree height, crown wide and stem girth in $1.3 \mathrm{~m}$ above the ground, were measured by using laser telemeter of Leica DISTRO D-5.

\section{Assessment the values of chlorophyll fluorescence}

Assessment of chlorophyll fluorescence was performed by non-destructive method of tree leaves in the field conditions of studied localities. The measurement was done by using pulse fluorimeter instrument FMS- 2 (Fluorescence 
Monitoring System) of Hansatech firm and valuated basic parameters resulting from fluorescence induction curve of chlorophyll $a$. Measurement was made after 30-min adaptation of assimilation organs to darkness with the use of leaf clamp chamber with 7-mm diameter saturation aperture (Kmet' et al., 2009). Measurements were made three times during the growing season, it means in turn of June-July, late August and in turn of September-October. For measurement, the script with following characteristics was set up: WAIT $=10.0 \mathrm{~s} ; \mathrm{F}_{\mathrm{v}} / \mathrm{F}_{\mathrm{m}}=2.5 \mathrm{~s}$ (lasting period), intensity of saturation radiation in maximum level $-100=20000 \mu \mathrm{mol} \cdot \mathrm{m}^{-2} \cdot \mathrm{s}^{-1}, 0.8 \mu \mathrm{s}$ (lasting of light pulse). A Halogen lamp with 594-nm amber modulating beam frequency was used as a light source. We used the Halogen lamp OSRAM $64255-8 \mathrm{~V}, 25 \mathrm{~W}$ unit.

By using these set up parameters at the instrument, a measurement was made on 10 leaves of each three chosen trees at the perimeter of the crown in 1.5-2.5 m height above ground. The all measured values were continually saved to the control unit of FMS-2 instrument and subsequently exported and evaluated by software MODFLUOR 32. Measured physiological parameters $\mathrm{F}_{\mathrm{v}} / \mathrm{F}_{\mathrm{m}}$ were statistically evaluated by using analysis of variance (ANOVA) test and the Kruskal-Wallis test for significance between assessed two study territory and three assessed periods.

\section{Results and discussion}

\section{Assessment of climate characteristics during study period}

The assessment of chlorophyll $a$ fluorescence and visual morphological characters of Sycamore maple in Nitra city has been performed mostly during high daily temperature. During June, $30.7{ }^{\circ} \mathrm{C}$ was achieved, in July $36.8{ }^{\circ} \mathrm{C}$ and August until $37.5^{\circ} \mathrm{C}$ in maximum values. The month sum of precipitation achieved $10.2 \mathrm{~mm}$ in June, $172 \mathrm{~mm}$ in July and $57.7 \mathrm{~mm}$ in August 2015. Summer time in Nitra city should be consider quite drought (Table 1). The behavior of meteorological elements, as shown from the measured values, at the Nová Ves nad Žitavou study locality was almost similar to that from Arboretum Mlynany SAS climate station (Table 2). In air temperature characters was slightly cooler, in rainfall more wet considering local storm occurrence in August. Within following months of September and October, there were also indicated obvious differences between assessed localities in measured meteorological dates as shown in Tables 1 and 2. During measurement of tree chlorophyll values, anti-cyclone weather type was dominated on both localities

T a b l e 1. Evaluation of climate characteristics - Nitra, 2015.

\begin{tabular}{|l|c|c|c|c|}
\hline Month & \multicolumn{3}{|c|}{ Air temperature ${ }^{\circ} \mathbf{C}$} & Rainfall mm \\
\hline & Max & Min & Average & Sum \\
\hline June & 30.7 & 7.9 & 19.9 & 10.2 \\
\hline July & 36.8 & 7.9 & 23.6 & 17.2 \\
\hline August & 37.5 & 10.0 & 23.5 & 57.7 \\
\hline September & 33.7 & 3.9 & 17.5 & 33.2 \\
\hline October & 22.4 & -1.6 & 10.5 & 54.8 \\
\hline
\end{tabular}

According to the measured meteorological characters during summer time in Nitra, that period is consider as extreme dry, which is confirmed by graphical interpretation of SPI and SPEI as shown in Figures 1 and 2. The negative values of indexes means dry conditions, the positive means wet ones. Dry period begins at down fall under -1 value and ends above 
T a b l e 2. Evaluation of climate characteristics - Nová Ves nad Žitavou, 2015.

\begin{tabular}{|l|c|c|c|c|}
\hline Month & \multicolumn{3}{|c|}{ Air temperature ${ }^{\circ} \mathbf{C}$} & Rainfall mm \\
\hline & Max & Min & Average & Sum \\
\hline June & 30.4 & 6.0 & 15.09 & 64.7 \\
\hline July & 37.3 & 6.2 & 23.2 & 18.4 \\
\hline August & 36.9 & 10.9 & 22.7 & 165.8 \\
\hline September & 35.8 & 9.3 & 22.3 & 61.2 \\
\hline October & 20.9 & -0.3 & 10.13 & 44.4 \\
\hline
\end{tabular}

zero level. Dry conditions defined by SPI and SPEI indexes have being expressed deviation from the mean values of theoretical distribution of measured values and, therefore, relative deficiency but not complete absence of the rainfall. Both indexes have had 30 days cumulative period. It means that index expressed for specific day of the derogation rainfall and the previous 29 days (Štastný et al., 2015).
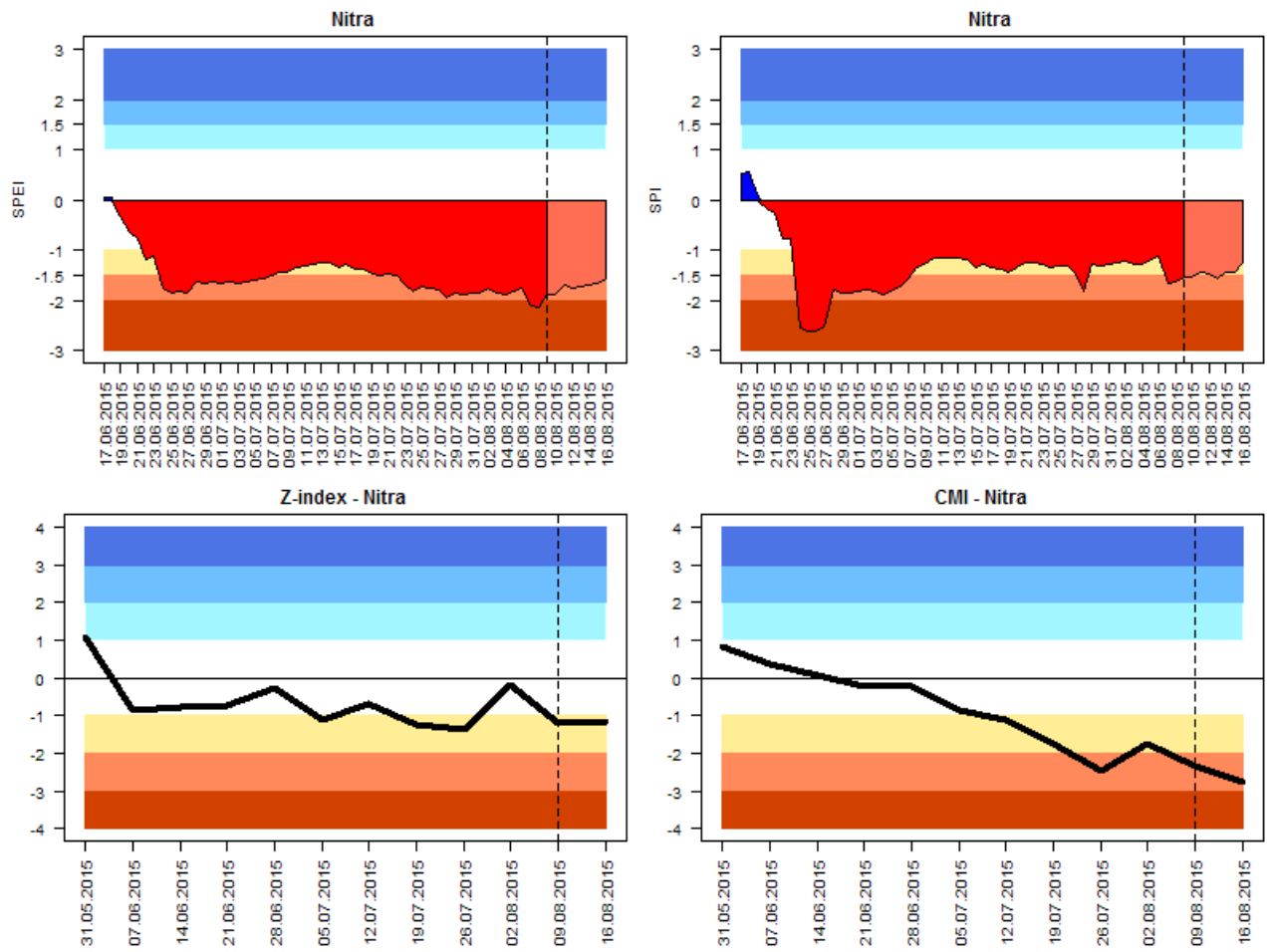

Fig. 1. Time evolution of SPEI parameter - Nitra, 2015.

Fig. 2. Time evolution of SPI parameter -Nitra, 2015. 


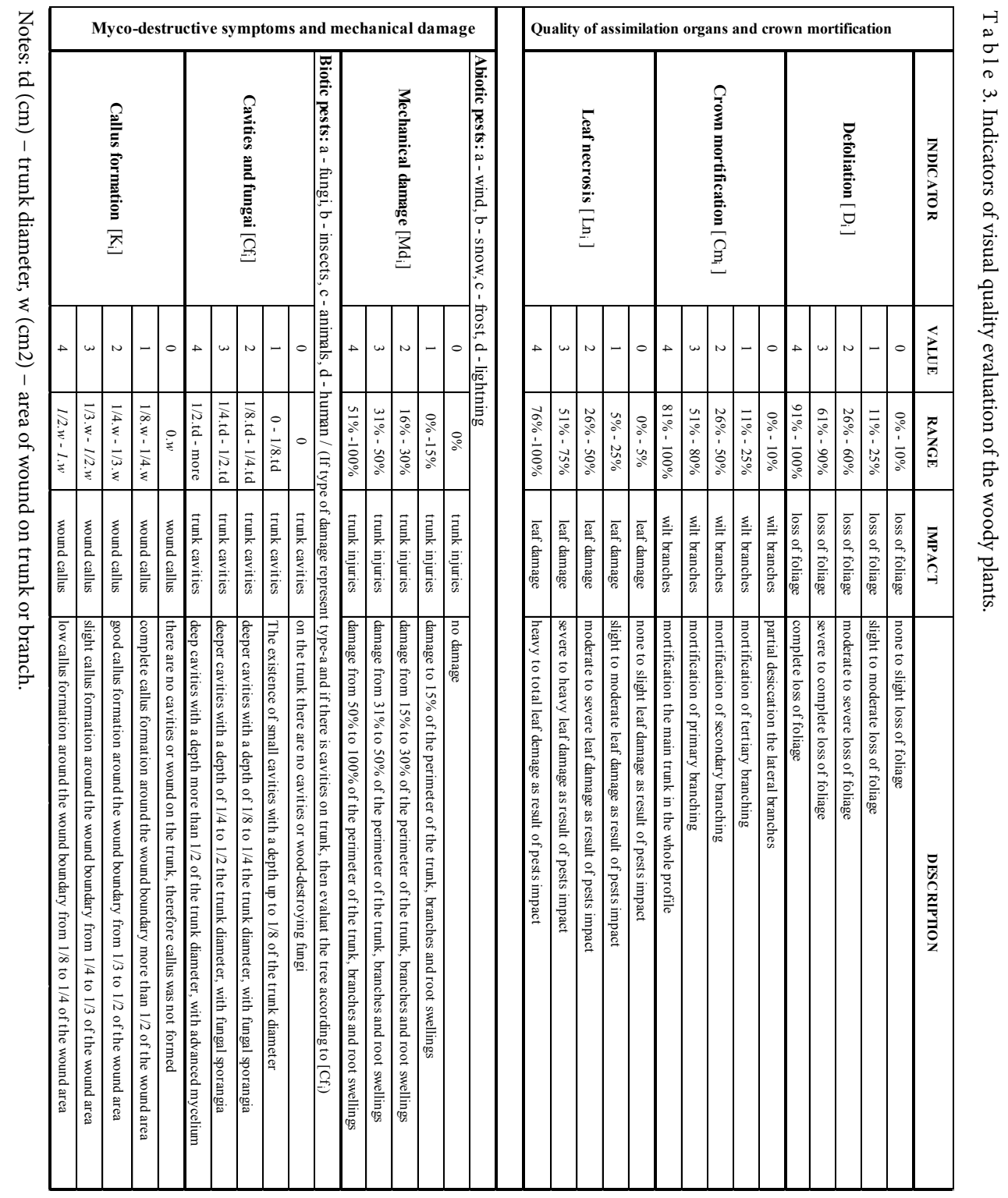




\section{Visual assessment of tree characters}

The results of visual assessment of the tree characters grown in city conditions shows slightly defoliation and relatively significant die-back of tree crowns, as well as leaf necrosis in the second evaluation period (Table 3). Quality index achieved 9.33 points in the first period and 10.33 in the second evaluation periods (Table 4). In the rural park of the comparable locality, all the assessed tree characters indicate better values in both measured periods than in city environment. Quality index reached of 2.66 points in first period and the same value of 2.66 in the second one. Quality index reached better values on comparable locality of Nová Ves nad Žitavou park in all indicators as were the quality of assimilation organs, destructive characteristics of the crown and trunk (Table 5).

T a b l e 4. Visual trees assessment in Nitra city.

\begin{tabular}{|c|c|l|c|c|c|c|c|c|c|}
\hline Measurement & $\begin{array}{c}\text { Tree } \\
\text { number }\end{array}$ & \multicolumn{1}{|c|}{ Latin name } & $\boldsymbol{D}$ & $\boldsymbol{O k}$ & $\boldsymbol{N i}$ & $\boldsymbol{M p}$ & $\boldsymbol{V d}$ & $\boldsymbol{K}$ & $\boldsymbol{Q}_{\boldsymbol{I}}$ \\
\hline 1. & 1 & Acer pseudoplatanus L. & 1 & 2 & 2 & 2 & 0 & 3 & \multirow{2}{*}{9.33} \\
\hline 1. & 2 & Acer pseudoplatanus L. & 2 & 2 & 1 & 3 & 0 & 3 \\
\hline 1. & 3 & Acer pseudoplatanus L. & 1 & 2 & 1 & 1 & 0 & 0 & \\
\hline 2. & 1 & Acer pseudoplatanus L. & 1 & 2 & 3 & 2 & 0 & 3 & \multirow{2}{*}{10.33} \\
\hline 2. & 2 & Acer pseudoplatanus L. & 2 & 3 & 2 & 3 & 0 & 3 \\
\hline 2. & 3 & Acer pseudoplatanus L. & 1 & 2 & 3 & 1 & 0 & 0 & \\
\hline
\end{tabular}

Notes: $D$ - crown defoliation, $\mathrm{Ok}$ - dieback of the crown, $\mathrm{Ni}$ - necrosis of leaves, $\mathrm{Mp}$ - mechanical damage, $\mathrm{Vd}$ incidence of cavities in the trunk or branches, $K$ - wound callusing, $Q_{1}-$ quality index.

T a b l e 5. Visual trees assessment in park of Nová Ves nad Žitavou.

\begin{tabular}{|c|c|l|c|c|c|c|c|c|c|}
\hline Measurement & $\begin{array}{c}\text { Tree } \\
\text { number }\end{array}$ & Latin name & $\boldsymbol{D}$ & $\boldsymbol{O k}$ & $\boldsymbol{N i}$ & $\boldsymbol{M p}$ & $\boldsymbol{V d}$ & $\boldsymbol{K}$ & $\boldsymbol{Q}_{\mathbf{2}}$ \\
\hline 1. & 1 & Acer pseudoplatanus L. & 0 & 0 & 0 & 0 & 0 & 1 & \multirow{2}{*}{2.66} \\
\hline 1. & 2 & Acer pseudoplatanus L. & 1 & 2 & 1 & 1 & 0 & 0 \\
\hline 1. & 3 & Acer pseudoplatanus L. & 0 & 0 & 0 & 1 & 0 & 1 & \\
\hline 2. & 1 & Acer pseudoplatanus L. & 0 & 0 & 0 & 0 & 0 & 1 & \multirow{2}{*}{2.66} \\
\hline 2. & 2 & Acer pseudoplatanus L. & 1 & 2 & 1 & 1 & 0 & 0 \\
\hline 2. & 3 & Acer pseudoplatanus L. & 1 & 0 & 0 & 1 & 0 & 1 & \\
\hline
\end{tabular}

Notes: $\mathrm{D}$ - crown defoliation, $\mathrm{Ok}$ - dieback of the crown, $\mathrm{Ni}$ - necrosis of leaves, $\mathrm{Mp}$ - mechanical damage, $\mathrm{Vd}-$ incidence of cavities in the trunk or branches, $K$ - wound callusing, $Q_{2}$ - quality index.

\section{Assessment of chlorophyll a fluorescence on compared trees}

In the assessment of chlorophyll $a$ fluorescence indicators, we focused on the values of $\mathrm{F}_{\mathrm{v}} / \mathrm{F}_{\mathrm{m}}$ physiological parameter measured on Sycamore maple grown at both localities in all three measurement periods in particular and together. Table 6 shows overview of the measured statistical values of $\mathrm{F}_{\mathrm{v}} / \mathrm{F}_{\mathrm{m}}$ parameters. In the case of statistical valuation for all 
T a b l e 6. Statistical evaluation of $F_{v} / F_{m}$ parameter measured at two localities in all three measurement terms.

\begin{tabular}{|c|l|c|c|c|c|c|c|}
\hline $\begin{array}{c}\text { Measure- } \\
\text { ment }\end{array}$ & Locality & Median & $\begin{array}{c}\text { Standard } \\
\text { deviation }\end{array}$ & $\begin{array}{c}\text { Variation } \\
\text { coefficient }\end{array}$ & Minimum & Maximum & Range \\
\hline \multirow{2}{*}{$\mathbf{1}$} & Nitra & 0.836 & 0.0103 & $1.24 \%$ & 0.819 & 0.856 & 0.037 \\
\cline { 2 - 8 } & Rural park & 0.837 & 0.0195 & $2.33 \%$ & 0.790 & 0.867 & 0.077 \\
\hline \multirow{2}{*}{$\mathbf{2}$} & Nitra & 0.806 & 0.0192 & $2.38 \%$ & 0.773 & 0.832 & 0.059 \\
\cline { 2 - 8 } & Rural park & 0.826 & 0.0180 & $2.19 \%$ & 0.783 & 0.855 & 0.072 \\
\hline \multirow{2}{*}{3} & Nitra & 0.801 & 0.0106 & $1.34 \%$ & 0.780 & 0.821 & 0.041 \\
\cline { 2 - 8 } & Rural park & 0.824 & 0.0105 & $1.28 \%$ & 0.797 & 0.842 & 0.045 \\
\hline \multirow{2}{*}{$\mathbf{1 + 2 + 3}$} & Nitra & 0.814 & 0.0227 & $2.79 \%$ & 0.764 & 0.856 & 0.092 \\
\cline { 2 - 8 } & Rural park & 0.829 & 0.0173 & $2.09 \%$ & 0.783 & 0.867 & 0.084 \\
\hline
\end{tabular}

three measurement periods together, the median value has reached 0.829 at rural park and 0.814 in city conditions (Fig. 3). Statistical valuation of the average $F_{v} / F_{m}$ parameters by ANOVA test have confirmed significant differences between compared localities and achieved 24.68 values. Using Kruskal-Wallis test procedure, the measured $\mathrm{F}_{\mathrm{v}} / \mathrm{F}_{\mathrm{m}}$ parameters shows statistically significant differences between localities at limited values and 95\% confidence level (Table 7). Median difference parameter $\mathrm{F}_{\mathrm{v}} / \mathrm{F}_{\mathrm{m}}$ measured at both localities in three study periods together is shown in Figure 3. In the case of statistical assessment of the $\mathrm{F}_{\mathrm{v}} / \mathrm{F}_{\mathrm{m}}$ parameters at the first study period, no statistical significance in median values between compared localities were identified. ANOVA test shows statistically insignificant differences at $\mathrm{P}=1.000$ value (Fig. 4; Table 7). The obvious differences have been identified at standard deviation and coefficient of variation, when ranges of the recorded values were visible and smaller in city conditions. Based on the obtained results and assessed climate characteristics, it is stated that the measured parameters $\mathrm{F}_{\mathrm{v}} / \mathrm{F}_{\mathrm{m}}$ were influenced by almost favourable and balanced values of the air temperature and underground water content in city condition during the first period of early summer. In the second study period, high

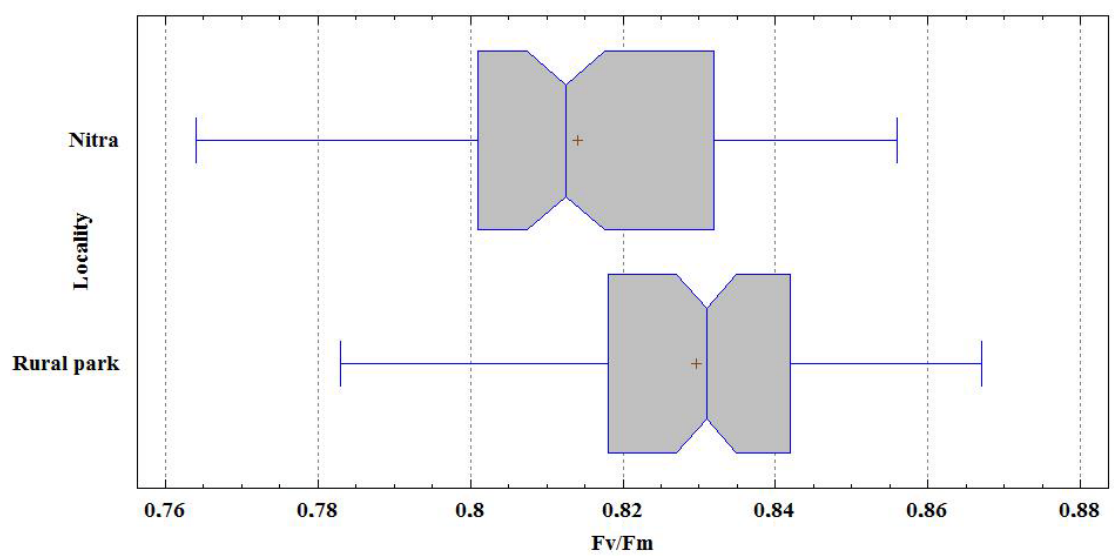

Fig. 3. Median difference of parameter $F_{v} / F_{m}$ measured at two localities in all three measurement terms. 
statistically significance differences in median values of $\mathrm{F}_{\mathrm{v}} / \mathrm{F}_{\mathrm{m}}$ parameter between localities have been recorded, when $\mathrm{P}=0.0001$ value at $95 \%$ confidence level. Median value reached 0.826 in rural park and 0.806 in city condition (Table 6). At the city locality, higher values in standard deviation and variation coefficient compared with rural park were recorded. All the measured values of $\mathrm{F}_{\mathrm{v}} / \mathrm{F}_{\mathrm{m}}$ were more compact and balanced at rural park locality (Fig. 5). The results obtained from second study period of chlorophyll $a$ fluorescence values and their differences between localities were caused by higher average air temperature and lower sum of rainfall during August in city conditions. At rural park locality, better climate condition for favorable assimilation process and tree growth was present (see Tables 1, 2). Evolution of measured $\mathrm{F}_{\mathrm{v}} / \mathrm{F}_{\mathrm{m}}$ parameters have showed nearly similar values during the first assessment period and expressive differences during the second period between compared localities. In the third assessment period, highest statistical differences has been recorded in median values of $\mathrm{F}_{\mathrm{v}} / \mathrm{F}_{\mathrm{m}}$ parameter between compared localities (Figs 6, 7; Table 7).

$\mathrm{T} \mathrm{a} \mathrm{b} \mathrm{l} \mathrm{e} \mathrm{7.} \mathrm{Analysis} \mathrm{of} \mathrm{variance} \mathrm{for} F_{v} / F_{m}$ parameter (ANOVA test) and comparation of medians (Kruskal-Wallis test) between assessed localities of Nitra city and rural park.

\begin{tabular}{|l|c|c|c|c|}
\hline Statistical Limits & \multicolumn{4}{|c|}{ Term of measurement } \\
\hline & $\mathbf{1}$ & $\mathbf{2}$ & $\mathbf{3}$ & $\mathbf{1 + 2 + 3}$ \\
\hline \multicolumn{5}{|c|}{ ANOVA test } \\
\hline P - value & 1.0000 & $0.0001^{\star * *}$ & $<0.0001^{\star * *}$ & $<0.0001^{* * *}$ \\
\hline F - ratio & 1.42 & 17.98 & 71.20 & 26.48 \\
\hline \multicolumn{5}{|c|}{ Kruskal- Wallis test } \\
\hline P - value & 0.6254 & $0.0001^{* * *}$ & $<0.0001^{\star * *}$ & $<0.0001^{\star * *}$ \\
\hline T - test & 0.23839 & 14.9027 & 33.812 & 20.21 \\
\hline
\end{tabular}

Notes: Significance: ${ }^{\star} \mathrm{P} \leq 0.5 ;{ }^{\star *} \mathrm{P} \leq 0.01 ;{ }^{* *} \mathrm{P} \leq 0.001$

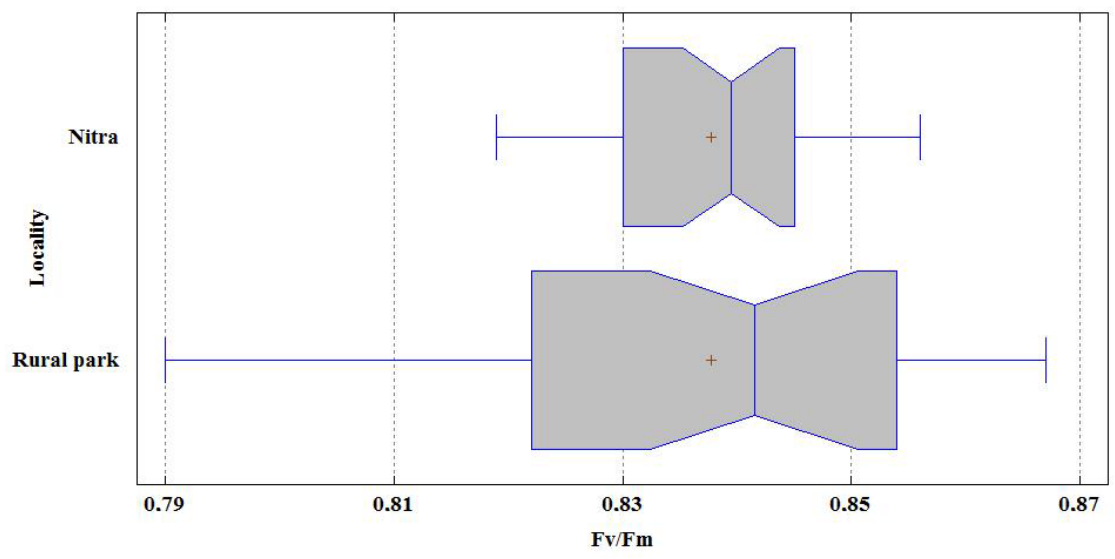

Fig. 4. Median difference of parameter $F_{V} / F_{m}$ measured at two localities in first term of measurement. 


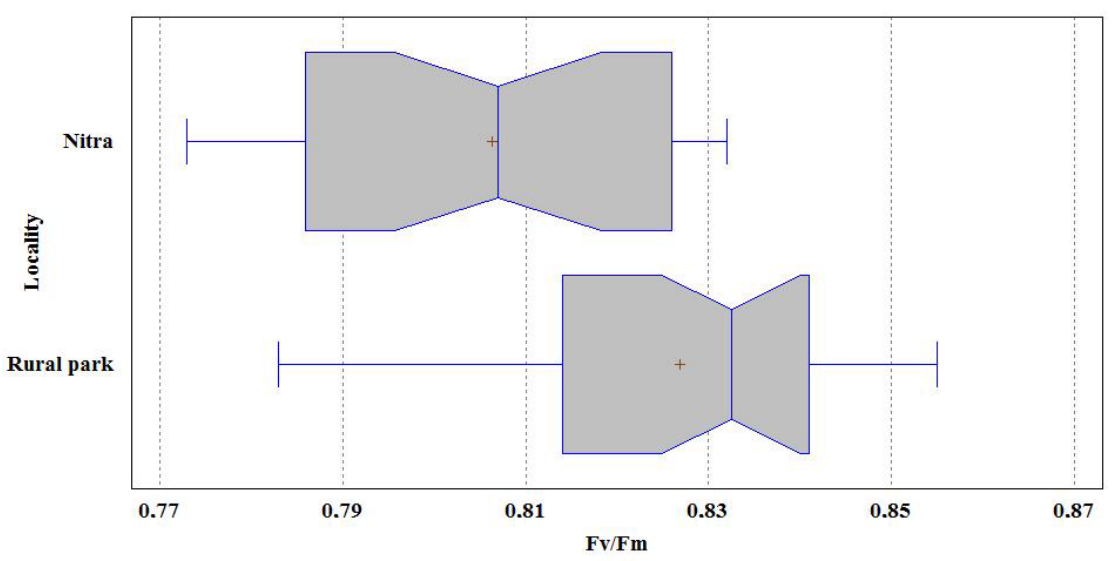

Fig. 5. Median difference of parameter $F_{v} / F_{m}$ measured at two localities in second term of measurement.

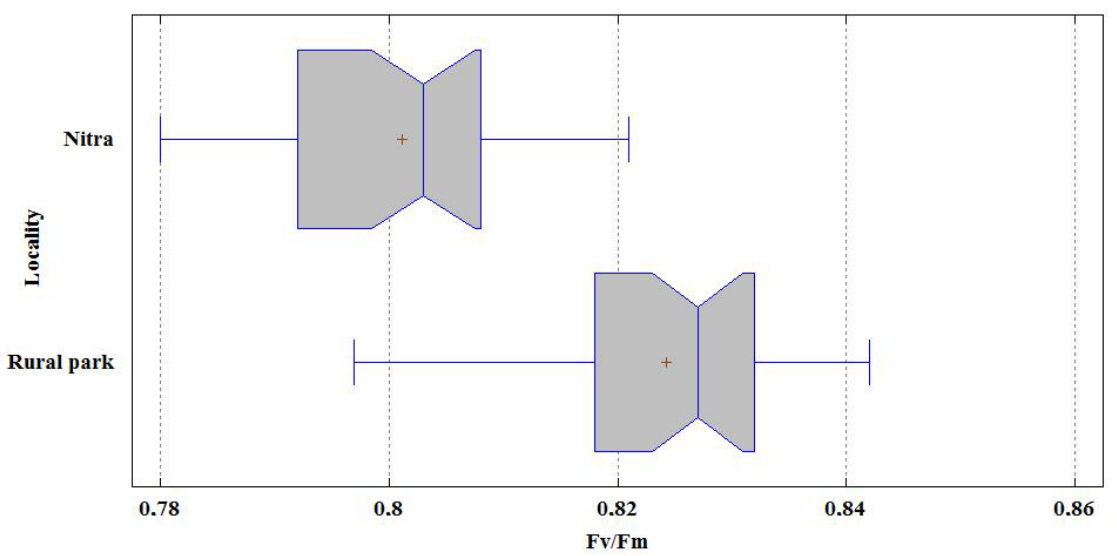

Fig. 6. Median difference of parameter $F_{v} / F_{m}$ measured at two localities in third term of measurement.

Besides presented air temperature and sum of rainfall values concerning Nitra city conditions, other article shows environmental load of assessed locality measured in 2012 year (Rózová et al., 2013), they are as follow: total air dust content $=0.060 \mathrm{mg} \cdot \mathrm{m}^{-3}$, volatile organic compounds $(\mathrm{VOC})=0.037 \mathrm{ppm}, \mathrm{SO}_{2}=0.018 \mathrm{ppm}, \mathrm{CO}_{2}=442.853 \mathrm{ppm}, \mathrm{CO}=2.299 \mathrm{ppm}$ and $\mathrm{NO}_{x}=0.016 \mathrm{ppm}$. At compared park study locality, any environmental load characteristics has not been measured, but important sources of emission and/or high transport that caused disturbance of assimilation organs in assessed tree species were not identified. The park locality might, therefore, be considered as relatively clean with environmental values based on the backgrounds. Another published contribution shows markedly differences in $\mathrm{F}_{\mathrm{v}} / \mathrm{F}_{\mathrm{m}} \mathrm{pa}$ rameters measured on assimilation organs of the birch (Betula verrucosa Ehrh.), linden (Tilia cordata Mill.), willow (Salix alba 'Tristis') and oak (Quercus robur L.) tree species grown in the Štúrova street and Sihot park in Nitra city (Supuka et al., 2010). 


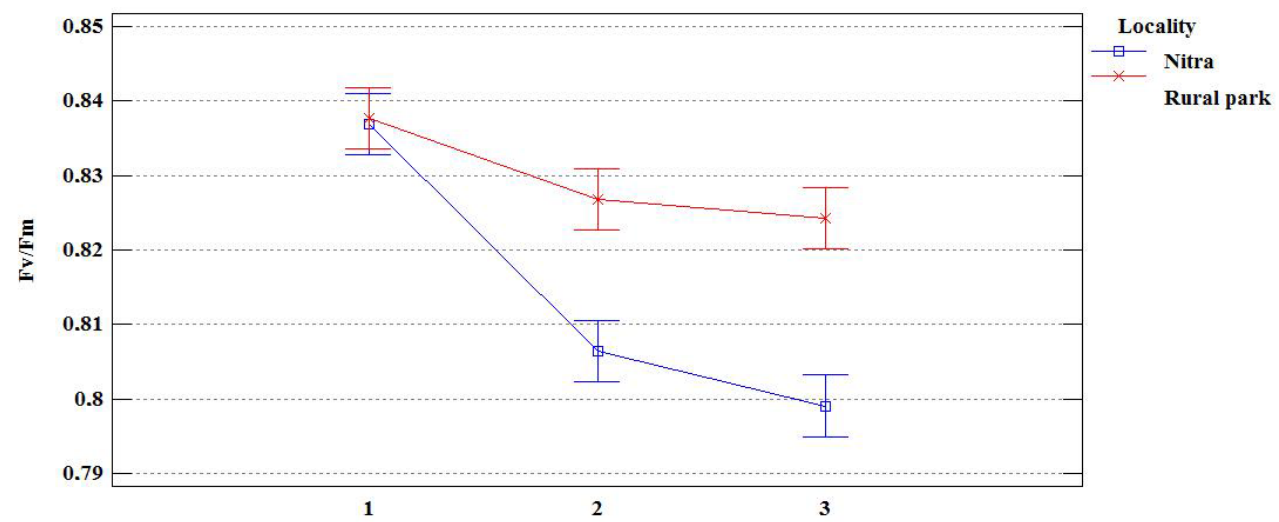

Fig. 7. Median difference of parameter $F_{v} / F_{m}$ measured at two localities

Notes: time of measurement: 1. - first measurement, 2. - second measurement, 3. - third measurement.

Similar results were published at the assessment of forest tree species on industrially load localities (Kmet, 1999) and reaction of plants under increased air temperature as stress factor and expressed by the level of $\mathrm{F}_{\mathrm{v}} / \mathrm{F}_{\mathrm{m}}$ parameters (Láposi et al., 2009). Influence of changed environmental conditions in European cities and their reflexion in growth and ecology physiological manifestation of the street trees has been already described in earlier publications (e.g. Bernatzky, 1978), which are being confirmed also in current time by the new significant markers.

\section{Conclusion}

Green spaces are important components that improve environmental, culture architectural and dwelling quality of the city settlements. On the other hand, the cities are characterized by multifactorial spectrum of the stress factors including climate changes with emphasis on increased air temperature and water deficiency. For the new settlement conditions, woody plants are tested for adaptability and resilience. This article deals with the assessment of visual characters of the chosen tree species and physiology biochemical markers as tools for tree response on changed environment. The assessment was made on chosen deciduous Sycamore maple (Acer pseudoplatanus L.) tree grown in Nitra city street and loaded by multifactorial stress factors but dominantly car's emissions, changed climate and marks of urban soils. As comparable locality was chosen, rural park in Nová Ves nad Žitavou was considered environmentally unloaded space. In the framework of visual symptoms, the six characters were taken for tree assessment. In the group of physiology markers, leaf chlorophyll $a$ fluorescence was used. The quality index achieved 9.33 points in the first and 10.33 in the second evaluation periods in the Nitra city and 2.66 at both assessed periods in the comparable rural park. In the group of physiological indicators, chlorophyll $a$ fluorescence marker was used, where parameter $\mathrm{F}_{\mathrm{v}} / \mathrm{F}_{\mathrm{m}}$ in average values reached 0.814 in the city and $\mathrm{F}_{\mathrm{v}} /$ $\mathrm{F}_{\mathrm{m}}=0.829$ in rural park. Within three study periods (June, August and September) of the 
assessed tree characters, in the second and third periods, statistically significant differences were recorded between compared localities of the urban conditions and rural park. It has been shown that the assessed characters and used methods are being convenient tools for the evaluation of tree response, adaptability and/or resilience in relation to changed environment. These processes should be used in the selection of the appropriate tree species for creation of the integrated urban green infrastructure.

Acknowledgements

The research was supported by the grant agency KEGA, project No. 003SPU-4/2014.

\section{References}

Antrop, M. (2004). Landscape change and the urbanization process in Europe. Landsc. Urban Plann., 67, 9-26. DOI: 10.1016/S0169-2046(03)00026-4.

Bernatzky, A. (1978). Tree ecology and preservation. Amsterdam, Oxford, New York: Elsevier.

Craul, P.J. (1992). Urban soil in landscape design. New York: John Willey and Sons.

Dobrovolný, P., Řezníćková, L. \& Brázdil N. et al. (2012). Klíma Brna. Brno: Masarykova Univerzita.

Douglas, J. (2012). Urban ecology and urban ecosystems: Understanding the links to human health and wellbeing. Current Opinion in Environmental Sustainability, 4(4), 385-392. DOI: 10.1016/j.cosust.2012.07.005.

Gallé, A., Haldimann, P. \& Feller U. (2007). Photosynthetic performance and water relation in young pubescent oak (Quercus pubescens Wild.) trees during drought stress and recovery. New Phytol., 174(4), 799-810. DOI: 10.1111/j.1469-8137.2007.02047.x.

Gáper, J. \& Gáperová S. (2009). Cavities as important part of tree vitality assessment in settlements (in Slovak). In S. Bernadovičová \& G. Juhásová (Eds.), Dreviny vo verejnej zeleni (pp. 193-198). Nitra: UEL SAV.

Gilbert, O.J. (1989). Ecology of urban habitats. London: Chapman and Hall.

Innes, J.L. (1990). Assessment of tree conditions. London: HMSO.

Jasenka, M. (2011). Influence of city condition on biological processes of woody vegetation (in Slovak). Doctoral Thesis. Nitra: SPU.

Kmet', J. (1999). Chlorophyll fluorescence as indicator of the stress load of woody plants and applying in forestry (in Slovak). Vedecké Štúdie, 3/1999. Zvolen: TU.

Kmet', J., Ditmarová, L. \& Kurjak D. (2009). Physiological and biochemical parameters as potential drought indicator (in Slovak). Acta Facultatis Forestalia Zvolen, 51(3), 67-76.

Kuczman, G. \& Feriancová L. (2013). Principles of green space creation in rural settlements (in Slovak). Nitra: SPU.

Láposi, R., Veres, Sz., Lakatos, Gy., Oláh, V., Fieldsend, A. \& Mészáros I. (2009). Response of leaf traits of European beech (Fagus sylvatica L.) samplings to supplemental UV-B radiation and UV-B exclusion. Agric. For. Meteorol., 149, 745-755. DOI: 10.1016/j.agrformet.2008.10.023.

Leuzinger, S., Vogt, R. \& Korner C. (2010). Tree surface temperature in an urban environment. Agric. For. Meteorol., 150, 56-62. DOI: 10.1016/j.agrformet.2009.08.006.

Lichtenthaler, H.K. \& Miehé J.A. (1997). Fluorescence imaging as a diagnostic tool for plant stress. Trends Plant Sci., 2(8), 316-320. DOI: DOI: 10.1016/S1360-1385(97)89954-2.

McKinney, M.L. (2006). Urbanization as major cause of biotic homogenization. Biol. Conserv., 127(3), 247-260. DOI: 10.1016/j.biocon.2005.09.005.

Oke, T.R. (2006). Towards better scientific communication in urban climate. Theor. Appl. Clim., 84(1-3), 179-190. DOI: 10.1007/s00704-005-0153-0.

Paganová, V., Hillová, D., Lichtnerová, H., Moravčík, L., Raček, M. \& Šajbidorová V. (2015). Plant species for urban environment in condition of the water deficiency (in Slovak). Nitra: SPU.

Pejchal, M. (1997). Assessment of the tree vitality (in Czech). In M. Marko (Ed.), Mestský park (pp. 9-32). Nitra: SPU.

Quigley, M.F. (2004). Street trees and rural co specifics: Will long lived trees reach full size in urban conditions. Urban Ecosyst., 7, 29-39. DOI: 10.1023/B:UECO.0000020170.58404.e9.

Rózová, Z. et al. (2013). Environmental aspect of urban conditions (in Slovak). Nitra: FPV UKF. 
Sobocká, J., Jad’uda, M., Ružeková-Poltárska, K. \& Šurina B. (2007). Urban soils- an example of Bratislava (in Slovak). Bratislava: VUPOP.

Štastný, P., Labudová, L. \& Turňa M. (2015). Selected indexes for the drought monitoring (in Slovak). Aktuality SHMU, 3, 10-12. http://www.shmu.sk/sk/?page=2049\&id=595

Slováková, L. \& Mistrík I. (2007). Physiological processes of the plants in stress conditions (in Slovak). Bratislava: FPV UK.

Střelcová, K. \& Kmet' J. (2003). Physiological aspects of drought in forest stands (in Slovak). Les, 59(9), 8-10.

Supuka, J., Benčat', F., Bublinec, E., Gáper, J., Hrubík, P., Juhásová, G., Maglocký, Š. \& Vreštiak P. (1991). Ecological principles of verdure creation and protection (in Slovak). Bratislava: VEDA, vyd. SAV.

Supuka, J., Kmet', J. \& Jasenka M. (2010). Selected parameters of chlorophyll $a$ fluorescence in leaves of woody plants in city conditions. Acta Horticulturae et Regiotecturae, 13, 1-7.

Tóth, A., Halajová, D. \& Halaj P. (2015). Green infrastructure: a strategic tool for climate change mitigation in urban environments. Ecology \& Safety, 9, 132-138. www.scientific-publications.net 